\title{
Re-examining the BMW-Rover Affair: A Case Study of Corporate, Strategic and Government Failure? ${ }^{1}$
}

\author{
David Bailey \\ Coventry University Business School, \\ Priory Street, Coventry, CV1 5FB, UK \\ Email: david.bailey@coventry.ac.uk
}

\author{
Alex de Ruyter \\ Canterbury Christ Church University, \\ North Holmes Road, Canterbury, CT1 1QU, UK \\ Email: alex.de-ruyter@canterbury.ac.uk
}

\begin{abstract}
This paper analyses corporate and government strategies during the purchase, period of control and divestment by BMW of the car manufacturer Rover over the period 1994-2000. The paper examines three types of 'failure'. It views BMW's purchase of Rover as a 'corporate failure', with British Aerospace keen to sell Rover to raise cash and with BMW not realising the real condition of Rover. It then moves on to examine BMW's 'divide and rule' strategies with regard to working conditions and subsidy-seeking and its decision to sell Rover as an example of 'strategic failure'. Finally, it considers the 'hands-off nature of British policy towards such transnational firms, and BMW in particular, as an example of 'government failure'. The paper concludes by raising the possibility of an EU-wide policy towards transnationals, especially in terms of monitoring the activities of such firms.
\end{abstract}

Keywords: BMW; Rover; takeover; disinvestment; transnationals; strategic failure; monitoring.

Reference to this paper should be made as follows: Bailey, D and A de Ruyter (2011) 'Re-

examining the BMW-Rover Affair: A Case Study of Corporate, Strategic and Government Failure?', Int. J. Automotive Technology and Management, Vol. x, No. x, pp.xx-xx.

Biographical notes: David Bailey is a Professor at Coventry University Business School, UK. He has written extensively on industrial and regional policy and globalisation, especially in relation to the auto industry. He was the Principal Investigator on a recent Economic and Social Research Council (ESRC) project looking at the impact of the MG Rover closure and the policy response to this. He is co-editor of The Recession and Beyond: Local and Regional Responses to the Downturn, and also Industrial Policy Beyond the Crisis. Regional, National and International Perspectives (both Routledge). He is also Chair of the Regional Studies Association.

Alex de Ruyter is Professor of Human Resource Management at Canterbury Christ Church University, UK. He has written extensively on industrial relations, HRM practices, the minimum wage, labour markets, and precarious forms of employment. He was a co-Investigator on a recent Economic and Social Research Council (ESRC) project looking at the impact of the MG Rover closure and the policy response to this, and another ESRC project looking at the agency work in the health sector.

\section{Introduction}

BMW today enjoys a very positive media profile in the UK linked to the perceived success of its MINI brand, and investment undertaken at its plants in the UK. At the turn of the century, though, things were rather different, and this paper analyses corporate and government strategies

\footnotetext{
1 The support of the Economic and Social research Council under award number RES-000-22-2478 is gratefully acknowledged.
} 
during the purchase, period of control and divestment by BMW of the car manufacturer Rover over the period 1994-2000.2 This is significant not simply in terms of it being an interesting historical case study of a major transnational purchase and dis-investment but also because it raises important issues regarding the relationship between governments and transnational firms, and indeed over the impact of such firms on regions and communities in an enlarging and integrating Europe, which still remain relevant today. In particular, by exploring the BMW-Rover affair this paper examines: (i) the strategies pursued by certain auto transnationals in an increasingly 'free' European market; (ii) the policy stance of governments in the light of such strategies; and (iii) a possible national and supranational (EU) dimension for policy in the light of (i) and (ii). The latter is especially pertinent given recent developments with General Motors in Europe, in its attempts to play off countries against each other to secure aid packages for its restructuring efforts, and given on-going over-capacity in the European industry which may warrant European oversight of restructuring as was seen with the steel industry in the 1980s.

The paper is structured as followed: section 2 offers a background by viewing BMW's purchase of Rover as a 'corporate failure', with British Aerospace keen to sell Rover to raise cash and with BMW not realising the real condition of Rover; section 3 examines BMW's 'divide and rule' strategies with regard to working conditions and subsidy-seeking and its decision to sell Rover as an example of 'strategic failure'; section 4 looks at the 'hands-off' nature of British policy towards such transnational firms, and BMW in particular, as an example of 'government failure'; and section 5 raises the possibility of an EU-wide policy towards transnationals given the issues raised. Some final comments conclude the paper.

\section{Corporate Failure? BMW's Purchase of Rover}

The purchase by BMW of the Rover Group in 1994 at the time marked the end of British-owned mass car manufacturing. The reasons for the (then) disappearance of the British owned industry were tied up in a complex vortex of inter-related and long-term factors, including a failure to integrate and achieve economies of scale and scope, macro-economic instability, the particular short-termism of British finance-industry relations, fratricidal industrial relations and misguided government policy interventions (Williams et al, 1994a; Berkeley et al, 2005; Holweg and Oliver, 2005; Bailey et al, 2008; Coffey, 2009). ${ }^{3}$ Such problems were compounded by the decision of a series of major British owned component part suppliers to partly relocate operations to the European mainland following Britain's entry to the Single Market, while adopting a more aggressive pricing strategy with the British car assembly sector (see Cowling 1986; discussed further in Coffey and Thornley 2009). Rover itself was the remnant of a government creation of the 1960s, the

${ }^{2} \mathrm{On}$ foreign direct dis-investments in the auto industry, see Coffey and Thornley (2010) on Ford at Dagenham, and Bailey (2003) on the policy response to BMW's withdrawal from Rover.

${ }^{3}$ Although care must be taken not to overlook industrial relations difficulties in other parts of Europe at this time. 
British Leyland Motor Corporation (BLMC, later BL, then Rover Group). This was brought together by the government merging British Motor Holdings and Leyland into one, in so doing bringing together several smaller car manufacturers (Austin, Morris, Triumph, Rover and Jaguar ${ }^{4}$ ) into a single firm, in probably the most prominent case of the so-called 'national champions' approach. This forced merger "was a mistake both in concept and in execution, reflecting a naïve belief in the advantages of size and in the ability of charismatic individuals to revive declining companies" (Owen, 1999) and led to a failure to integrate operations to achieve economies of scale and scope (Bailey et al, 2008). Moreover, opportunities were soon undermined by an asymmetry which saw BLMC attacked in own market by foreign transnationals but unable to respond similarly, combined with a lack of effective government support as openness to foreign investment over-rode any desire to support a national champion (Coffey, 2009). The firm was nationalised in the wake of the oil crisis in 1975 and privatised ten years later through a sale to British Aerospace (BAe), which was at the time diversifying away from aircraft. After the failure of its regional jet business, BAe sold Rover to BMW for $f_{800}$ million. As highlighted by Hutton (1999), the sale of Rover to a foreign transnational reflected both short-termism in the UK (in particular BAe's need for cash to keep shareholders happy) and the openness of the UK economy to penetration through foreign takeovers.

Rover thus became part of BMW, but probably not for the 'right' reasons, in terms of the potential impact on the West Midlands auto cluster. Quite why BMW bought Rover remains contentious. BAe was in need of cash and BMW wanted the prestigious four-wheel-drive Land Rover division so as to compete with Mercedes, Ford and GM, all of which had developed such vehicles. The latter was seen as necessary for BMW as at that time the firm did not have the resources or competencies to develop its own model to compete head-on in this new emerging segment. Unfortunately for workers and suppliers in the Midlands, it also acquired Rover as part of the package. To some observers an obvious question arose at this time (see Bailey et al, 1994): was this the way to plan the future of a strategic sector?

Another view is that BMW acquired Rover not only for its competencies in the four-wheel-drive area, but also to obtain "a manufacturing base in a country which had lower labour costs than Germany and... a [now] stable labour relations climate" (Owen, 1999) and as part of a longer term effort to internationalise, expand and diversify (Eckardt and Lemm, 2003). Certainly a year after the purchase, BMW's chairman, Bernd Pischetsrieder, argued "Britain had become the most attractive location in Europe for car production" (Owen, ibid) in the wake of sterling's exit from the Exchange Rate Mechanism. One objective might thus have been to put pressure on German workers to reduce costs, given that a lower cost production site was now available to the firm in

\footnotetext{
${ }^{4}$ Jaguar was separated and privatised in the 1980s, taken over by Ford in 1989, sold again to Ford's US parent
} in 1991, and sold with Land Rover to Tata in 2009. 
Europe (i.e. a divide and rule strategy). Whether or not this was the case, it soon became an ineffective strategy anyway vis-à-vis production in Germany given the significant appreciation in the value of sterling from 1994 onwards. At the time of the BMW takeover in 1994, sterling was valued at less than DM2.40, making car assembly in the UK attractive to incoming transnationals such as BMW. With sustained sterling appreciation during the mid to late 1990s, BMW planned for a turnaround strategy at Rover with sterling at around DM2.90 (House of Commons, 2000a: questions 176-178 and 186). Yet by January 2000 sterling had appreciated to the equivalent of DM3.20. Indeed, Church's (1999) estimates suggest that by July 1999 the Sterling effective exchange rate was overvalued by some $20 \%$. In evidence to the House of Commons (2000a), BMW put the exchange rate loss for Rover at some $£ 700$ million. This over-appreciation exacerbated problems for UK manufacturing, and for Rover in particular, making exports extremely difficult at a time when the company was in fact trying to re-orientate its sales towards export markets (and with some success before sterling appreciated so much). Rather than being able to use Rover in a divide and rule strategy against German plants (if that had been the intention), BMW instead had to use a divide and rule strategy against Rover, arguing that it might shift Rover production overseas unless costs were reduced and significant public subsidies for new product launches made available.

Whatever the precise reasons for BMW's acquisition, problems were immediately apparent given the shift in strategic decision-making away from the West Midlands region to Bavaria in Germany. While retaining a successful in-house 4 wheel drive operation in Land Rover, Rover under UK state ownership and then BAe ownership had relied on a joint venture (JV) with the Japanese firm Honda, including a series of (largely) Honda designs which were badged and sold as Rovers to the UK and European markets (Freysennet and Mair, 2000), ${ }^{5}$ on the one hand saving Rover considerable costs through a platform sharing strategy and potentially generating small profits, but on the other leaving it vulnerable to hard bargaining by Honda. ${ }^{6}$ Despite having an alternative strategy available via its Swindon assembly plant, Honda's senior executives were unimpressed when Rover was sold to a competitor, and the firm unsurprisingly quickly off-loaded its $20 \%$ stake in Rover after stating publically that it did not want BMW to gain access to technology it had licensed to Rover (Bailey et al, 1994: 133).

This is where Rover's effectively terminal round of problems began, because as commentators warned at the time of the sale (Bailey et al, 1994; Williams et al, 1994b), it was not clear what BMW could actually produce at Rover after the joint venture with Honda was terminated. Rover in effect missed out on a whole generation of possible new joint models with Honda, and just one joint Honda-Rover model programme, the Honda Civic / Rover 400 (later Rover 45) continued into

\footnotetext{
${ }^{5}$ Coffey (2009) makes the point that over time the cooperation between Rover and BMW developed so that more genuinely joint models were developed, with scope for Rover to supply its own engines.

${ }^{6}$ Brady and Lorenz (2001) emphasise the toughness of the deals struck by Honda with Rover.
} 
production. BMW was now on its own, and as Williams et al (1994b) highlighted, BMW simply did not have the ability to produce "competitive, space-efficient, light cars" and Rover jobs were thus at risk. Unfortunately the British government failed to heed such warnings regarding the BMW takeover. This does not imply that the joint venture with Honda was ideal for Rover either as the terms of agreement meant that even models that sold well such as the 200/400 failed to generate significant profits, at least for Rover (Coffey, 2009). In fact, Rover was not generating anywhere near the levels of cash required to finance new model development, and by the mid-1990s it was in danger of becoming essentially an assembler of Honda-designed cars (with the exception of its Powertrain engines division and Land Rover). However it was difficult to see how things could improve under BMW as it was clear that the latter was always going to struggle to develop small, front-wheel drive cars. If ownership by a foreign transnational was required, it would have been much better to court one whose resources and corporate strategy had a closer degree of alignment with that of Rover, such as Ford (which had talks with the government on buying the then AustinRover in 1986), or Volkswagen (which had also shown interest in 1987) ${ }^{7}$ which could have extended its strategy of platform-sharing across its brands, thereby recovering development costs more easily. Instead, as Hutton noted at the time of takeover, "BMW's key models might compete head to head with the British, so rationalization in favour of Munich is inevitable" (reprinted in Hutton, 1999: 58). Indeed, one interpretation of the original move by BMW to acquire Rover was potentially to eliminate a possible rival and extend its product profile while preserving the core BMW brand (Brady and Lorenz, 2001).

Perhaps not surprisingly, therefore, through a combination of model obsolescence (as BMW struggled to bring new models to market), marketing mistakes, and broader economic forces such as the rise in the value of sterling, Rover sales declined and losses grew to $£, 400$ to $£, 500$ million per year by the late 1990s. Whilst BMW invested heavily in the Land Rover / Range Rover assembly plant at Birmingham-Solihull and at the Oxford-Cowley assembly plant, the position of the Birmingham-Longbridge assembly plant was soon in doubt, with BMW threatening to shift production of the new MINI (designed by Rover Group) to another location if productivity was not improved and new (allegedly more 'flexible') deals on working conditions were not agreed with the workforce (Bailey et al, 2008). ${ }^{8}$ A productivity deal was agreed by workers in November 1998 and involved 2,500 voluntary redundancies, amidst concerns that BMW could shift production elsewhere (Financial Times, 1998). Similarly, in March 1999 BMW threatened to shift production to Hungary if a state aid package was not agreed by the government to build a new model range, the medium-sized R30 (the replacement for the Rover 400 / 45). A f152 million subsidy package was agreed with the UK government in 1999 for a planned $f_{1.7}$ billion BMW investment in

\footnotetext{
7 Owen, 1999. Coffey (2009) highlights the point that strategies in effect collided.

${ }^{8}$ See also Stewart et al (2009) for a critical account of labour relations in the British car industry more generally, a study partly informed by the experience of BMW at Cowley.
} 
Birmingham-Longbridge and new model launch (the MINI). Meanwhile BMW had begun to rationalise its supply chain and shift sourcing overseas given the new relative cheapness of imported parts to the UK in the context of the over-valuation of sterling, with Rover under BMW control shifting some $£ 1$ billion of its $£ 4$ billion annual spending on components out of Britain (Financial Times, 1999e; 2002). But after a complaint by the German sports-car manufacturer Porsche, the European Commission announced that it would investigate the $f_{152}$ million launch-aid package under EU Single Market state-aid rules. However, before the lengthy Commission investigation was finalised, BMW declared in March 2000 that it was pulling out of Rover anyway.

With the BMW pull-out, the Birmingham-Longbridge facility and MG and Rover brands were initially to be sold to a private venture capital firm, Alchemy partners, which would re-badge cars as MGs and dramatically downsize production and employment to focus on sports cars, with the loss of some 5,000 jobs at Longbridge and many more in the auto supply-chain. The Alchemy deal quickly fell through, however, leaving the firm exposed and facing possible closure. At this point the UK government set up the Rover Task Force to deal with the possible loss of as many as 25,000 jobs at MG Rover and in the regional supply chain. In May 2000, the firm was split up by BMW. The Phoenix consortium bought the MG and Rover brands and the BirminghamLongbridge assembly plant for a symbolic $f_{10}$ (Chinn and Dyson, 2000). Land Rover was sold to Ford for $£_{1.8}$ billion along with Rover's design facility at Gaydon (and later to Tata), and the Oxford-Cowley plant was retained by BMW to produce the new MINI, with production of the Rover 75 in turn shifting to Birmingham-Longbridge. The Phoenix consortium kept Rover running for another five years, finally collapsing in 2005 with the loss of 6300 jobs and some $£ 1.3$ billion owing to creditors (Bailey et al 2008; Bailey et al, 2010). The latter came as little surprise to commentators who - as early as 2002/3 - had seen the firm in trouble (Bailey, 2003), with the unsustainable position of the firm evidenced by the way it consumed what assets it had. This is because, despite the hopes raised in 2000, BMW's withdrawal effectively left Rover dead on its feet. The cancellation of the R30 project, which was the key small-medium sized model being developed under BMW as a replacement for the aging Rover 45, meant that once again a whole cycle of model development was missed (Holweg and Oliver, 2005). Rover was henceforth seriously exposed in the market as its obsolescent model range became less and less attractive to buyers. The firm had only a very limited time horizon in which to find a potential partner.

In summary, it was clear to several commentators (Williams et al, 1994b; Bailey et al, 1994) that BMW's purchase of Rover in 1994 was a corporate mistake for BMW and also highly likely to cause severe problems for Rover. As Wolf later commented (Financial Times, 1999b), "BMW did not realise how bad a buy Rover would be". BMW's Chairman Pischetsrieder was under the impression that BMW was acquiring an independent, stand-alone firm with research and development capabilities. In fact, Rover (with the exception of its Powertrain engines division and Land Rover) 
had been at risk for some time of being over-dependent on Honda for new model development. It was difficult to see how BMW - a relatively small firm itself at the time with little experience of producing space efficient front-wheel-drive cars - could have quickly developed the new models that Rover needed. As one commentator later noted; "technically the two manufacturers are culturally as different as could be. Basic (car) layouts are so different that one could not be introduced to the other without huge change" (BBC News, 1999a). In a sense this had anyway pre-dated the actual takeover: Coffey (2009) stresses the 'production counterfeit' of Rover's 'foolhardy' efforts at marry a BMW-style marketing strategy with a supply regime based on experiments with 'Japanisation'.? But the fact that the merger did not work well for either side should not have come as a great surprise. Numerous studies have found that on balance most mergers and acquisitions do not increase profitability, with disruption caused by the merger itself often outweighing any cost savings from increased scale (Cowling et al, 1980; Ravenscraft and Scherer, 1989). This is often the case in the auto industry - witness Daimler-Chrysler and GM-Saab.

\section{Strategic Failure? BMW's Control of Rover.}

In the wake of the BMW purchase, the position of Rover plants at Birmingham-Longbridge and Oxford-Cowley was always going to be in doubt, despite the so-called 'assurances' the (Conservative) British government had obtained from BMW in 1994 at the time of the takeover over employment and production. With Rover models increasingly obsolescent, BMW simply did not have the capability or the resources to develop new models in time. As a result, production of the Rover 100, 600 and 800 models was ended before replacements were available. Whilst the Rover 75 eventually replaced the ageing 600 and 800 series, production of the 100 model was ended well before the MINI (later retained by BMW) was ready for market in what was the critical, highvolume supermini segment. And with dwindling output, Longbridge's productivity figures looked even worse than they otherwise might have been simply because the existing plant was being used well below capacity. Of course, Longbridge needed modernising, but the presentation of such poor productivity figures in 1999 may have been an attempt by BMW to intensify its bargaining leverage with workers and the government. ${ }^{10}$ Indeed, regarding the productivity gap between Longbridge and BMW plants in Germany, car industry commentator Garel Rhys noted that it was "disingenuous of Pischetsrieder (former BMW chairman) to put the gap at 30 per cent" (Financial Times, 1999e).

What further exacerbated the fragility of job security in the supply chain across the West Midlands region, however, was BMW's transnationality, a dimension that did not exist so obviously under the

\footnotetext{
${ }^{9}$ For a critical discussion see Coffey (2006).

${ }^{10}$ In 1999 a Longbridge worker produced 33 cars per year against 98 by a Nissan worker at Sunderland (BBC News, 1999). Caution was needed in making such comparisons, however. By 2002, with fewer workers and more cars going down the Longbridge production lines, output per worker had risen to 50 per year (Financial Times, 08/07/02). Vertical integration, model mix and automation are also all factors that can impact on headline labour (body count) productivity, and are rarely controlled for.
} 
previous Rover/Honda joint venture. Under BMW ownership the asymmetry of power between the locationally immobile Longbridge/Midlands workforce and the transnationality of the firm was intensified, with BMW able to credibly threaten an exit from Longbridge. Strategic decision-makers in BMW's Bavarian headquarters were able to exploit the apparently low productivity figures as justification for possibly closing Birmingham-Longbridge and threatening to relocate elsewhere (notably Hungary) unless the workforce accepted allegedly more 'flexible', low-cost practices and the government subsidised new investment. An added complication came as the composition of that elite changed, with Pischetsrieder ousted as chairman after shareholders (i.e. the Quandt family) lost patience over the size of losses at Rover. ${ }^{11}$ That one Bavarian family held such a significant say over the future of an estimated 25,000 Midlands workers (at Rover and in the supply chain in the West Midlands) is a vivid illustration of the concept of strategic failure, which we explore next.

It was Stephen Hymer (1975) who made the critical connection between theories over the structure and organisation of transnational firms and the structure and organisation of the broader international economy that would result from their pre-eminence. Hymer envisaged a world economy where managerial activities are spatially differentiated, contributing to patterns of uneven development across countries and regions. In this scenario, low-level (Level I) day-to-day activities are spread around in search of low costs and market access, with the coordination of such activities (Level II) more geographically concentrated given the need for skilled workers and communication/information systems; while top management, responsible for goal determination and strategic planning (Level III), is spatially concentrated in major cities. As control over such decisions becomes more firmly enshrined in the hands of a few elite decision-makers within these increasingly dominant and mobile firms, the risks of 'strategic failure' become more likely, with the objectives of the elites making those strategic decisions at the centre conflicting with wider interests in society (Cowling and Sugden, 1994). The end result is social inefficiency, with the economic system yielding inappropriate outcomes for the society (or societies) served by that economy. At the heart of this is the 'industrial' versus 'corporate' strategy issue. 'Corporate' strategies are seen as 'top down' strategies for industrial development conceived by and in the interests of strategic decision makers within large transnational corporations, whereas 'industrial' strategies are those devised by and in the interests of a wider set of actors in the community.

At the European level, such strategic failure has been manifested in a number of ways, including the divide and rule of workers and governments by transnationals, with workers and regions being played off against each other by firms eager to reduce costs. Peoples and Sugden (2000) provide a detailed theoretical framework for analysing such strategies towards workers by transnational firms,

${ }^{11}$ Again, caution is needed in interpreting such figures; analysts have estimated that the 1995 reported loss of $£ 148$ million would, under British accounting standards, have been recorded as a $£, 93$ million profit (BBC News, 1999). 
emphasising distributional issues for why firms produce in various countries. In so doing, they argue that firms may become transnational and produce in different countries so as to weaken the bargaining power of the firm's workforce and hence increase profits, at the expense of its workforce (ibid). Such a divide and rule analysis also implies that strategic decision-makers within such firms will spread certain production activities around (i.e. lower order activities in Hymer's analysis) in order to pursue such strategies. While there is limited evidence available on divide and rule practices, much of what is available relates to the automotive industry and its workforce, on which Peoples and Sugden (2000) cite several cases. These include Chrysler (which considered transferring production from Britain to France in the 1970s after labour unrest in Britain), General Motors in its dealings with Vauxhall workers in Britain regarding the siting of a new engine plant, as well as the (better documented) activities of Ford. In particular, they quote a CIS (Counter Information Services) Report of 1978 suggesting that Ford dual-sourced components for its Fiesta model in the 1970s in order to reduce labour's bargaining power. In addition, during the 1990s, Ford relocated production of different models around its European plants, which could be interpreted as significant in bringing to bear an implicit "threat effect" on workers in British factories to catch-up with productivity levels elsewhere (Bailey et al, 1999). BMW itself (after pulling out of Rover) reportedly wrote to workers at its Cowley plant in Britain after they rejected a pay offer in 2001, to warn them that future investment at the plant might be threatened (BBC News, 2001). In addition, firms may try to use the heightened perception of the mobility of capital to threaten to shift overseas "even if no move is really being entertained" (Ramsay, 1995). For example, during the early 1990s, Mercedes-Benz pressured German workers by making a "show of examining sites in the UK, France and the Czech Republic" to accept concessions before retaining production inside Germany. ${ }^{12}$

In this way, as Peoples and Sugden (2000) note more generally, the fear that the firm may become transnational may temper the behaviour of workers. ${ }^{13}$ However, there are limits to such approaches by national firms as workers may not believe that the firm will make new investments; "the crucial point is that any improvements in a firm's bargaining power as a result of its ability to become a transnational are guaranteed only by its actually being a transnational" (Peoples and Sugden 2002). Furthermore, in being to able to negotiate with - and possibly play off governments and workers transnationals have key advantages over national firms, as they "tend to have greater expertise, intelligence of non-market environments, access to political elites, and skills in the exercise of influence and negotiation compared to smaller national firms without international production networks" (Sally, 1996). As with evidence on divide and rule more generally, it cannot be proved that BMW purchased Rover to pursue a divide and rule strategy - and indeed sterling appreciation negated such an option vis-à-vis German plants - but later events do indicate that BMW was

${ }^{12}$ For parallel cases outside the auto sector at this time, see Ramsay (1995).

${ }^{13}$ This is one subtext of Coffey and Thornley's (2010) analysis of Ford's disinvestment in Britain. 
prepared to engage in divide and rule activities. It was evident that multinational divisions within the workforce had emerged between Germany and the UK. As it became apparent that BMW management wanted to divest itself of Rover, relations between the UK and German representatives on the company European Works Council (EWC) deteriorated. The German union representatives on the EWC were aware of BMW intentions "because of German co-determination rules and in-firm co-management practices; British worker representatives, by contrast, were kept in the dark" (Greer and Hauptmeier, 2008: 79).14

Indeed such an approach was used by BMW to persuade the Longbridge workforce to agree to 2500 job losses and new shift patterns by 1998. By 1999, BMW had developed the strategy to a different level, with the Birmingham-Longbridge plant itself threatened unless a government subsidy award was forthcoming. In particular, BMW claimed that it was considering a site in Hungary as an alternative to producing the MINI at Longbridge. In several carefully chosen comments aimed at levering more subsidy from the British government and implicitly threatening Longbridge workers, BMW "played its cards with skill, wringing concessions from unions and governments" (The Guardian, 1999a). ${ }^{15}$ For example, an un-named BMW/Rover executive was quoted as early as 1998 as stating "we have to consider the possibility of building abroad" (BBC News, 1998). This was followed by several warnings from BMW executives in March 1999 as negotiations reached a critical stage. Helmut Punke, a BMW director was quoted as stating “....as a business corporation we have to look at alternatives and it (Hungary) is a serious alternative" (BBC News, 1999b). In what appeared to be a coordinated approach, incoming BMW chairman Joachim Milberg warned that "the comparative alternative of Hungary would have advantages in comparison to Longbridge", whilst leaving open the possibility of investment at Longbridge (BBC News, 1999). The pressure was maintained by Milberg; "the longer the negotiations drag on, the greater will become the likelihood of a production site outside Britain. We are a global player" (BBC News, 1999c). As Wolf (Financial Times, 1999b) commented;

Thus BMW and the government are in an auction in which both have an interest in concealing how far they are prepared to go. BMW's threat to shift production to Hungary may, for example, be genuine. But it is also an obvious negotiating ploy.

This echoed a similar set of events surrounding Chrysler and its British subsidiary Rootes almost a quarter of a century earlier, when Chrysler was described as "holding a pistol to the head"16 of the British government. Either the government was to subsidise BMW's investment in Longbridge more heavily, or BMW would relocate to Hungary.

14 Indeed, an interview by the authors with the then Convenor of the main trade union at MG Rover in early 2005 suggested that BMW had informed German Works Council representatives that if it were to retain Rover, it would "go bankrupt".

${ }^{15}$ Negotiations between BMW and the British government were described as a game which "can be summed up in one word: brinkmanship" (Morgan, quoted in The Guardian, 1999).

${ }_{16}$ Quote taken from Harold Wilson giving evidence to the House of Commons Expenditure Committee (House of Commons, 1976). On the Chrysler case in the 1970s see also Bailey et al (1994) and Hood and Young (1977). 
In this way, BMW attempted to manipulate the environment of negotiations with the government and workers so as to maximise its bargaining power (for example in its use of productivity figures, in using the Hungarian option, and in levering money from the British government and changes from the workforce) before pulling out of Longbridge completely. BMW's threat to shift production was seen as credible precisely because it was a transnational producing in Britain, Germany and North America, and had the ability to shift production to a low cost base in central Europe. The Hungarian option itself was also potentially credible given its low labour costs, reasonable skills base, geo-political proximity to key European markets, the existence of its recently established transplant assembly sector and the possibility of subsidy support for going there.

Finally, the manner in which the elite controlling BMW attempted to dispose of Rover attracted much criticism. The House of Commons (2000) criticised BMW for its "incompetence and excessive secrecy", arguing that it "may not have devoted as much care and attention as it could and should have done to seeking an appropriate company to take the Rover small cars business off its hands". The result of this "lack of candour" (ibid) was that the British government was denied an early opportunity to make the case for keeping the Rover as one entity. In effect, a small elite of decision makers made the dis-investment decision with profound implications for the firm, its workers, and the regional economy. The government did later support efforts to find a buyer for the remaining rump of Rover, but this came after the break up of the firm was already announced. It is to the government's role that we turn next.

\section{$4 \quad$ Government Failure? The 'Informational Deficit'.}

The passive/reactive position of the British government throughout the BMW-Rover affair (the BMW purchase of Rover in 1994, the subsidy decision in 1999, and in the months before BMW's withdrawal in 2000) warrants careful examination. Firstly, there is the issue of the takeover itself. As noted, BMW was seen by several commentators as an inappropriate owner at the time of its takeover of Rover, yet the government allowed the takeover with no attempt to look at alternatives, whether domestic or foreign. This was a key mistake; if a foreign owner was required, as mentioned earlier, Volkswagen would have been much more suitable in that it would have been able to extend its strategy of sharing platforms across brands to Rover. The case here is not anti-inward investment per se (although it should be noted that foreign control brings risks as well as opportunities), but rather centres on the suitability of the acquiring firm (whether domestic or foreign) both for the acquired firm and the local production system based around that firm.

Just as when Chrysler bought the British car firm Rootes back in the 1960s, the Conservative government in 1994 negotiated various guarantees or assurances from BMW over employment, production and design, and development in Britain. The then President of the Board of Trade 
Michael Heseltine claimed that he was "proud that it was one of my ministers who asked for these assurances and got them" (quoted in Bailey et al, 1994). Remarkably, it had been Heseltine himself who - a few years previously - had identified possible dangers if the car industry became completely controlled by foreign transnationals (Heseltine, 1987, p113, our emphasis):

"An ominous development has been an increase in foreign ownership and control. Foreign investment and interest is, of course, to be welcomed, but control has its dangers. For the major parts of the British motor industry to fall entirely into foreign bands would leave it a bostage to decisions in Detroit, Paris, Turin and perhaps Tokyo. Experience shows, time and time again, that when the going gets tough, as it always will in such a cyclical industrial sector, foreign subsidiaries (which in this case means subsidiaries in Britain) will bear the brunt of the cutbacks. The skills in research and development tend to be lost".

Later events surrounding BMW and Rover should never have occurred, therefore, as BMW had given assurances or guarantees to maintain output, employment and R\&D in Britain. In practice, such assurances were largely empty, just as with Chrysler-Rootes thirty years earlier, in effect being another 'political escape valve' for the government to avoid criticism of the deal. That the government (including the Labour government from 1997) saw no real need for the assurances in the first place is reflected by the fact that they were never followed up. There was no attempt to monitor BMW's Rover operations, despite their significance for the Midlands' economy.

As a result, the government was in an extremely weak position when it later entered negotiations on subsidies, having allowed BMW to shape the environment within which they took place, most notably regarding the supposed Hungarian option. The scale of potential job losses arising from a Birmingham-Longbridge closure if BMW followed through on its threat to shift production to Hungary was at the time politically unacceptable to the British government, and in June 1999 the latter agreed to provide a subsidy package of $£ 152$ million (including local government assistance) for a BMW investment at Birmingham-Longbridge of $£ 1.7$ billion. Whilst the Hungarian option prompted an increase in the subsidy offered by government, it was not clear that BMW had any real intention of shifting operations to Hungary. Indeed, the European Commission appeared sceptical as to whether Hungary was really an option and started to investigate the deal (Financial Times, 1999d); similarly the Hungarian government itself indicated there had been no actual application for aid (BBC, 1999d). If so, the British government failed to understand the divide and rule approach $\mathrm{BMW}$ was attempting to use. If the government had been monitoring BMW/Rover's operations, it may have better understood the company's strategy to extract concessions from both itself and the workforce. In contrast, BMW was not passive; it tried to proactively shape the environment of negotiations to maximise the benefits accruing to it, before pulling out and retaining the modernised Rover plant at Oxford-Cowley that still today assembles the MINI.

In another aspect of the deal, the British government claimed that it was adopting a new stance in its negotiations on subsidies with foreign transnationals. As Trade and Industry Secretary Stephen Byers stated at the time (BBC News, 1999f, our emphasis): 
"I wanted the Longbridge agreement to be one which heralded a new approach to government assistance to industry - a new approach which reflects a long term commitment and not a quick fix. That is why I sought guarantees on productivity targets, raising skills and substantial investment from the company itself. Guarantees have been given in all these key areas."

The government aimed to pay the subsidy in three tranches and BMW was to be required to repay the money if the new set of guarantees were not met. Yet in practice this was hardly a "new approach". The historical reference point is again Chrysler back in 1975; after threatening to withdraw from Britain, it gained a $£_{162.5}$ million aid package. Two years later it withdrew from Britain anyway, selling Rootes to Peugeot with "the British government left to read about the sale in the newspapers" (Jones, 1990). As regards undertakings Chrysler had made, "not one of the commitments had been honoured" (Dunning in Stopford and Turner, 1985). The guarantees obtained from BMW in 1999 were also vague, with no indication of how the government intended to measure and monitor them. For example, productivity could increase simply if more cars went down the underused Birmingham-Longbridge assembly lines or simply if fewer workers were employed, and skills might "improve" anyway with new investment. The vagueness itself suggests that the government had little or no intention to monitor all along. Indeed, some ministers were clearly unhappy with such an approach anyway. One minister at the Department of Trade and Industry was even quoted as stating (Financial Times, 1999a),

"I am not sure we should be telling BMW how to run Longbridge... There is something odd about a Labour government effectively encouraging BMW to sack big chunks of its workforce every few months, since that would be easiest way to improve productivity."

Rather, there was simply the hope was that the $£ 1.7$ billion BMW investment would create a new state-of-the-art assembly facility at Birmingham-Longbridge, as it had done at Oxford-Cowley. Yet even before BMW pulled out, commentators were warning that this was a high-risk strategy: with its executive market then under pressure, BMW simply did not produce enough cars to support new model development at Rover (BBC News, 1999e). The long-term commitment the government claimed it had gained was illusory, as witnessed by the subsequent BMW withdrawal from Rover in 2000.

This lack of monitoring and follow up was exposed by the fact that the government was caught largely unawares when BMW announced in March 2000 that it was selling Rover. This was despite several early warnings signs. For example, analysts warned as early as February 1999 that BMW might sell Rover (BBC News, 1999). This was followed by reported comments from BMW's sales director Henrich Heitmann (reported in the Sueddeutsche Zeitung in January 2000) that BMW "won't have the time we need" to re-establish Rover, and that in relation to selling or closing Rover, "nobody can completely rule out this ultimate solution" (BBC News, 2000). Indeed, BMW claimed in evidence to a Select Committee hearing that it had warned the government "that Rover was in survival mode and it was five minutes to midnight" (House of Commons, 2000a: question 173). Regardless of whether this was the case, the House of Commons Select Committee highlighted the 
"failure in the Government's intelligence-gathering mechanism", noting that the government had little direct intelligence from Munich (House of Commons, 2000):

the machinery of Government could and should have done more to pick up the early warning signs of BMW's waning commitment to Longbridge in particular and the Rover Group in general.

This was viewed by the House of Commons (2000) as symptomatic of either insufficient or ineffective liaison between the government and BMW, and possibly other auto manufacturers. Again there were parallels to Chrysler some thirty years previously, when the House of Commons (1976) had noted the "passive role" of government, with question marks over the information available to government (see Bailey et al, 1994). It seems that little had been learned twenty-four years later.

Government failure towards the BMW-Rover affair therefore took a number of forms:

(i) A failure of competition policy, in allowing the sale of Rover to an inappropriate buyer in the first place (i.e. BMW) despite warnings at the time that this was an unsuitable purchaser. This was despite the fact that - at the time - competition policy allowed a 'public interest' test which could have been used to block the takeover;

(ii) A failure to impose adequate safeguards on BMW's behaviour (e.g. a commitment not to shift Rover production out of Britain or to break up or sell the group);

(iii) A failure to effectively monitor and follow up BMW's strategy and investment, with the result that it did not pick up early warning signs and was taken by surprise when BMW announced that it was pulling out.

Underpinning these policy failures was ignorance of the possible effects of transnational firms and indeed a blind belief in the positive value of foreign investment, including takeovers in the UK. If the government had originally questioned or at least delayed the BMW take-over back in 1994, time and space might have been found to map out an alternative path for Rover with a more suitable owner, or even with Rover remaining in a revised Joint Venture with Honda, which was willing to increase its stake whilst not taking majority control. The government, however, saw no need for such action, as it had no appreciation (despite warnings) that BMW was an inappropriate buyer "until it was much too late to do anything about the mess" (Williams et al, 1994b). As Bailey et al (1994) detail, the welcoming attitude of successive British governments to foreign transnationals goes back decades, which they see as unique in giving such firms a free rein and in having a lack of information over their activities and impact. This 'informational deficit' can be seen as a key factor in government failure in the UK. This would appear to suggest a role for governments so as to properly examine the strategies and impact of such firms in order to bargain with them, with such monitoring at a national level coordinated by a European-level policy in order to better understand divide and rule strategies. 
The case for arguing for an industrial policy at the EU level is narrower than for that at a national level (see Geroski, 1990). However, such a role does exist in various areas, for example in supranational competition policy, in tackling trans-border externalities, and with particular relevance to this paper, in preventing transnationals from playing off national and regional governments against each other so as to increase subsidies. The BMW-Rover affair would appear to be an example of the latter, with the Hungarian "threat" deliberately deployed to maximise leverage in negotiations with workers and the government. The end result of such divide and rule strategies in the auto sector is strategic failure in the sense that governments subsidise transnationals at the taxpayers' expense, and workers suffer through the erosion of job security and through the need to be ever more 'flexible' over working arrangements. Indeed when the subsidy package was agreed in March 1999 the Financial Times (1999c) commented that "the UK government and its EU partners should seek to end the absurdity of competing to subsidise an industry suffering from chronic overcapacity".

National and regional governments are thus being played off against each other, via a race to attract new inward investment in the sector, as well as trying to hang on to existing auto transnationals' activities. The more recent strategies of GM in trying to off-load GM Europe operations, and in later seeking subsidies for its remaining operations, can also be seen in such a light. GM engaged in a process of inviting bids from subsidiary plants across Europe to compete for new lines of production with "plants being pitted against each other" (da Costa and Rehfeldt, 2010: 69) on the basis of least-cost (Greer and Hauptmeier, 2008: 88).17 However, the "coercive comparisons" engaged in by companies such as GM Europe has propelled counter-developments in the organisation of labour, with unions increasingly engaging in "labour transnationalism" - i.e., "the spatial extension of trade unionism through the intensification of co-operation between trade unionists across countries using transnational tools and structures" (ibid. 77). For example, in contrast to the Rover-BMW experience outlined earlier, the European Works Council (EWC) at GM organized a Europe-wide day of action on the $25^{\text {th }}$ January 2001 by 40,000 workers against the then proposed closure of GM's Luton plant (ibid. 87) and attempted to develop a "European-level strategy of transantional solidarity" (da Costa and Rehfeldt, 2010). Whilst the closure still went ahead, negotiation with the EWC led to affected workers being transferred to a nearby van-making plant (ibid.). Such solidarity has even been in evidence when large wage differentials exist between countries, such as with GM's operations in Germany and Poland (Bernaciak, 2010)..18

17 GM appears to have the most capability to engage in coercive comparisons, as it followed a deliberate production strategy of setting up parallel lines of production across countries through widespread platform sharing. In contrast the other three firms (Ford, Daimler and VW) displayed varying degrees of specialisation across countries and hence had a lesser ability to undertake such actions (Greer and Hauptmeier, 2008).

18 Although some degree of pragmatism was present here too, with the Polish union originally agreeing to a 3 year wage freeze and significantly lower wages for new hires, to "embed" GM in its Gliwice plant. However, once this initial period had passed the Polish union became more militant and cooperative with its 
Even in the context of fiscal competition, there may still be the substitution of FDI-subsidies for other areas of government expenditure in the context of a heightened emphasis on 'regional competitiveness' and the perceived role therein for inward FDI (Bristow, 2010). For example, Renault/Nissan obtained $f_{4} 40$ million in British government subsidy to produce the last generation Micra at its plant in Sunderland (Financial Times, 2002a), after Nissan president Carlos Ghosn "repeatedly warned" in 2001 that Nissan might shift production elsewhere in Europe because of the high value of sterling (Gilson, 2002). Indeed, there would be appear to be much evidence to suggest that national, regional and local governments compete, sometimes fiercely, for footloose transnational investment in a number of sectors including auto (Financial Times, 2011), with this inter-governmental competition taking the form of a negative or at best zero sum game (Amin and Tomaney, 1995). As noted above, EU Competition Policy aims to circumscribe the provision of state aids, yet Besley and Seabright (1999) argued that in practice it approves most if not all applications and that policy fails to avoid wasteful competition to attract FDI. This is, in essence, a specific illustration of Sally's (1996) observation that "there is no hard-and-fast 'international policy regime' on MNE (multinational enterprise) activity... various UN, OECD and EU codes on MNE behaviour are not enforceable in international and national laws and cannot be taken too seriously".

Given both this strategic failure and the informational deficiencies of governments highlighted above, there is a legitimate role for EU policy in this respect in monitoring the activities of transnationals so as to prevent such strategies being pursued. In this regard the decision of the (then) EU Competition Commissioner Karel Van Miert to investigate the BMW deal after a complaint from Porsche over unfair subsidies was a welcome move, with the Commission asking BMW for "convincing evidence" that it would have shifted operations to Hungary if British financial assistance was not forthcoming (BBC News, 1999g). Equally, however, the length of time between the submission by the British government of its aid notification and the Commission's decision to mount an inquiry was criticised by the House of Commons (2000) as "most unfortunately timed and largely unnecessary... at such a delicate time for the future of Rover". There would therefore appear to be lessons for EU level policy in that such investigations need to be conducted rapidly so as not to deter investments, and should be backed up by on-going monitoring of the behaviour of such firms (which in turn might enable more rapid investigations when they were deemed necessary).

As a pre-requisite for this, the European Commission would need to develop a monitoring facility so as to understand the on-going strategies of transnational firms. Linking this back to the need for

international counterparts, joining the Delta Group in 2005: a "union cooperation structure designed to prevent a 'beauty contest' between the five European factories constituting the 'Delta' production platform during the new Astra site selection process" (Bernaciak, ibid. 125). 
the British government (and other EU governments) to monitor so as to be able to negotiate on more equal terms with such firms and to follow up on compliance with guarantees, this suggests the need for monitoring at different tiers of governance, encompassing perhaps EU, national and regional levels. This would accord with earlier views of the European Parliament, which called in the late 1990s for a European Monitoring Platform to back up a code of conduct for European transnationals (see Financial Times, 1999).

The case for a multi-tiered European monitoring approach as a first step in countering the power of transnationals has been detailed previously (Bailey et al, 1999). This might then be used to develop policy as regards subsidy giving, for example, if it became clear that the current approach is too lax - as Besley and Seabright (1999) suggest - and that transnationals are thus able to exploit loopholes to bid up subsidies. The European dimension of policy would be especially important in minimising the costs and improving the quality of monitoring, and in providing an added dimension for policy development. In the short run this would help governments and EU bodies in negotiating with such firms. Such an approach is relevant here as BMW, like other car firms, appeared to play a divide and rule game in an attempt to maximise gains for shareholders from taxpayers and workers before attempting to pull out with minimal consultation with government. If appropriate counter-strategies are to be developed then communities (workers, consumers and so on), governments and EU regulators need to monitor such firms and then to develop appropriate policies on the basis of that information. This could also assist in terms of providing 'early warning' systems for governments and communities affected by corporate dis-investments. The inability of the British government to develop a coherent strategy as regards Rover stemmed from its ignorance of BMW's own strategies. Of course, monitoring alone might well not have avoided the break-up of the firm nor saved remaining MG Rover workers from the firm's failure in 2005. Nevertheless, without greater attention to this information issue, governments will continue to make policy errors (such as allowing the sale of Rover to BMW, in failing to monitor so-called guarantees once Rover was taken over, in allowing itself to be played-off by BMW, and in being caught unawares when BMW announced it was pulling out).

In this context, auto manufacturers and other firms in oligopolistic consumer markets depend for their survival on superior brand image to charge premium prices. Such a firm's brand image could be tarnished in a key market if a campaign illustrating its divide and rule tactics were undertaken. This would accord with the view of Ramsay (1995; our emphasis), who noted that "it is only a wider climate of concern about the activities of multinationals which would counsel management caution - and then perhaps only if markets were threatened through image disfigurement". Thus one role for a monitoring body might be to act as a 'clearing house' in providing community groups with information on the activities and impact of transnationals. A government established, independent monitoring body might begin to build in a bottom-up way 'countervailing power' to that of 
transnational firms through networking with other monitoring bodies across Europe and social and community groups interested in the activities of such firms (see Bailey et al, 1999). Such an approach would be in line with Ramsay (1995), who suggests an EU-wide role for trade unions to scrutinise transnationals' strategies, "utilizing existing business information sources augmented by their own intelligence, which would allow a far more effective assessment of multinationals' likely manoeuvres and threats". This in turn would build on the nascent labour trans-nationalism outlined earlier.

\section{Concluding Comments}

This historical case study of BMW's purchase, control and dis-investment of Rover can be analysed from a number of different perspectives. Firstly, the takeover can be seen as an example of corporate failure, with BMW's strategic decision-makers not realising the condition that Rover was really in (i.e. increasingly reliant on Honda for new designs), and with BMW itself unsuitable at the time as an owner given its own relatively small size and lack of experience in producing small, space efficient front-wheel-drive cars. BMW may have been attracted by the then low labour costs in the UK given the exchange rate position in 1994, but this soon disappeared with the appreciation of sterling through the mid to late 1990s. This became a classic case of a takeover that simply did not work. Secondly, the episode can be seen as an example of strategic failure, where the interests of the elite running BMW clashed with the wider interests of Rover workers and suppliers. Strategic decision-makers in Munich appear to have used a divide and rule strategy in attempting to wring productivity improvements from Rover workers by threatening to shift production elsewhere, and similarly in attempting to gain subsidies from the British government, before deciding to pull out completely. Thirdly, the episode can be viewed as an example of government failure, with an illinformed government allowing an inappropriate takeover (a failure of competition policy), failing to impose adequate safeguards over the strategies of BMW, and failing to monitor the guarantees that it had obtained at the time of the takeover. As a result it was caught unawares when BMW announced it was either selling or closing Rover.

More broadly, the completion of the 'negatively-free' Single Market is arguably intensifying the risks of strategic failure occurring across Europe, as evidenced by such divide and rule strategies. Transnationals free from control have more strategic and geo-political space within which they can manoeuvre in order to achieve their corporate strategies. The 'top-down' strategies of such transnationals may be optimal for the elites making the strategic decisions or for their particular interest group, but may not be in the interests of wider communities. Such strategic failures necessitate public intervention at various levels; in particular, the case for a monitoring policy at regional, national and European level is stressed here. Such monitoring might: (i) provide governments with better information on which to negotiate with transnationals; and (ii) start to build countervailing power amongst government and community groups. Of course, if strategic 
failure is an important issue, intervention requires more than simply monitoring transnational firms in the auto sector. But monitoring transnational firms - including in the auto industry - might provide a starting point to develop appropriate strategies to counter divide and rule in Europe.

\section{References}

Amin, A and J Tomaney. 1995. The Regional Dilemma in a Neo-Liberal Europe, European Urban and Regional Studies, Vol.2 No.2.

Bailey, D. 2003. Globalisation, Regions and Cluster Policies: The Case of the Rover Task Force, Policy Studies, 2003, Vol.24, No.2/3.

Bailey, D, G Harte and R Sugden. 1994. British Policy Towards Inward Investment, Journal of World Trade, Vol.28, No.2.

Bailey, D, G Harte and R Sugden. 1999. Regulating Transnationals: Free Markets and Monitoring in Europe, in Keith Cowling, ed., Practical Proposals for Industrial Policy in Europe. London: Routledge.

Bailey, D, S Kobayashi and S MacNeill. 2008. Rover and Out? Globalisation, the West Midlands Auto Cluster, and the end of MG Rover. Policy Studies, Vol.29, Iss.3, 2008, 267-279.

Bailey, D, I Clarke and A de Ruyter. 2010. Private Equity and the Flight of the Phoenix 4? The Restructuring, Collapse and Impact of MG Rover in the West Midlands, Cambridge Journal of Regions, Economy and Society, Vol 3, Iss 3, 367-382.

BBC News. 1998. Pound May Drive Rover Abroad. 07/07/98. www.bbc.co.uk/news 1999. The Rover Breakdown. 05/02/1999. www.bbc.co.uk/news 1999a. The End of Rover is Nigh. 10/02/1999. www.bbc.co.uk/news 1999b. BMW Close to Rover Decision. 10/03/99. www.bbc.co.uk/news 1999c. Hopes Slipping for Longbridge. 30/03/99. www.bbc.co.uk/news 1999d. Deal Saves Rover Plant. 01/05/99. www.bbc.co.uk/news 1999e. BMW Gambles its Future. 23/06/99. www.bbc.co.uk/news 1999f. Rover Rescue Deal Secured. 23/06/99. www.bbc.co.uk/news 1999g. Rover Aid Under Threat. 21/07/99. www.bbc.co.uk/news 2000. BMW Denies Rover Closure Plan. 14/01/00. www.bbc.co.uk/news 2001. GM and BMW Face their UK Workers. 15/01/01. www.bbc.co.uk/news

Berkeley, N, T. Donnelly, D. Morris and M. Donnelly. 2005. Industrial Restructuring and the State: The Case of MG Rover, Local Economy, Vol.20, Iss.4, November, 360-371.

Bernaciak, M. 2010. Cross-border competition and trade union responses in the enlarged EU: Evidence from the automotive industry in Germany and Poland, European Journal of Industrial Relations, Vol. 16, No. 2, 119-135.

Besley, T and P Seabright. 1999. The Effects and Policy Implications of State Aids to Industry, Economic Policy, Vol. 28.

Brady, C and A Lorenz. 2001. The End of the Road. BMW and Rover - A Brand too Far. London: Prentice Hall.

Bristow, G. 2010. Limits to Regional Competitiveness, in J. Tomaney, ed., The Future of Regional Policy. London: The Smith Institute / Regional Studies Association.

Chinn, C and S Dyson. 2000. "We Ain't Going Away.” The Battle for Longbridge. Studley: Brewin Books. 
Church, K B. 1999. Properties of the Fundamental Exchange Rate in the Treasury Model, National Institute Economic Review, No.169, July 1999, 96-104.

Coffey, D. (2006) The Myth of Japanese Efficiency: The World Car Industry in a Globalizing Age, Cheltenham and Northampton, MA: Edward Elgar

Coffey, D. 2009. 'Production Counterfeits and Policy Collisions: BMW and Rover - a Salutary Tale, in M. Freyssenet, ed., The New Automobile World in the 21st Century, Basingstoke: Palgrave MacMillan.

Coffey, D. and Thornley, C. (2009) Globalization and Varieties of Capitalism: New Labour, Economic Policy and the Abject State, London and New York: Palgrave Macmillan

Coffey, D and C. Thornley 2010. Swing Plants and Punishments: a Study of a Ford Closure Decision', International Journal of Automotive Technology and Management, vol. 10, Iss. 2/3: 252-269.

Cowling, K. (1986) 'The internationalization of production and de-industrialization', in A. Amin and J. Goddard (eds) Technological Change, Industrial Restructuring and Regional Development, London: Allen \& Unwin.

Cowling, K, P Stoneman, J Cubbin, J Cable, G Hall, S Domberger and P Dutton. 1980. Mergers and Economic Performance. Cambridge: Cambridge University Press.

Cowling, K and R Sugden. 1994. Beyond Capitalism. Towards a New World Economic Order. London: Pinter.

Da Costa, I and U Rehfeldt. 2010. Global Restructuring of Transnational Companies: Negotiations in the Auto Industry, in C. Thornley, S. Jeffrys and B. Appay, ed.s, Globalization and Precarious Forms of Production and Employment. Challenges for Workers and Unions. Cheltenham: Edward Elgar.

Eckhart, A and Klemm, M. 2003. The Internationalization of a Premium Car Producer: the BMW Group and Rover Case, in M. Freyssent, K. Shimuzu and G Volpato, ed.s, Globalization or Regionalization of the European Car Industry? Basingstoke: Palgrave Macmillan.

Financial Times. 1998. BMW Deal May Not Save Car Plant. 05/12/98.

------ 1999. Transnationals Must Face Responsibilities, 16/1/99: 8.

1999a. Rover Plant Aid to be linked to Output. 13-14/02/99.

1999b. Carmaker's Auction. 22/3/99: 16.

1999c. Cash for Cars. 23/3/99: 25.

1999d. EU Casts Doubt on State Aid for Rover's Longbridge Plant. 29/04/99.

1999e. Rover Suppliers Warned to be More Competitive. 24/6/99: 9.

2002. Defiant Carmaker Foresees a Positive Route to the Future. 27/04/02: 3 .

2002a. Japanese Car Plants Top Productivity Table. 08/07/02: 8.

Freysennet, M and A Mair. 2000. De British Leyland à Rover: la Researche d'une Stratégie de profit pertinente, in M. Freysennet, A. Mair, K. Shimuzu and G. Vopato, ed.s, Quel modèle Productif? Trajectoires et Modèles Industriels des Constructreurs Mondiaux. Paris: La Découverte.

Geroski, P A. 1990. European Industrial Policy and Industrial Policy in Europe, in K Cowling and H Tomann, ed.s, Industrial Policy after 1992: an Anglo-German Perspective. London: Anglo-German Foundation.

Gilson, J. 2002. Aisa Meets Europe. Inter-regionalism and the Aisa-Europe Meeting. Cheltenham: Edward Elgar.

The Guardian. 1999. How Rover was Driven to the Brink. 22/03/99. 
1999a. German Bluff wins the Hand. 01/04/99.

Greer, I. and M Hauptmeier. 2008. Political Entrepreneurs and Co-Managers: Labour Transnationalism at Four Multinational Auto Companies. British Journal of Industrial Relations, Vol. 46, No.1, 76-97.

Heseltine, M. 1974. Where There's a Will. London: Hutchinson.

Hood, N and S Young. 1981. British Policy and Inward Direct Investment, Journal of World Trade Law, Vol.15, Iss.3.

House of Commons Expenditure Committee. 1976. Public Expenditure on Chrysler UK Ltd., Eighth Report from the Expenditure Committee. Session 1975-76, together with the Minutes of Evidence taken before the Trade and Industry Sub-Committee in Session 1976 and Appendices, Volumes I and II, HC 596-I and HC596-II. London: HMSO.

House of Commons Select Committee on Trade and Industry. 2000. Eighth Report. BMW, Rover and Longbridge: Report, together with the Proceedings of the Committee, Minutes of Evidence and Appendices. London: HMSO. Available at: http://www.publications.parliament.uk/pa/cm199900/cmselect/cmtrdind/634/63402.htm

House of Commons Select Committee on Trade and Industry. 2000a. Trade and Industry - Minutes of Evidence. London: HMSO. Available at:

http://www.publications.parliament.uk/pa/cm199900/cmselect/cmtrdind/383/00329a02.htm

Hutton, W. 1999. 'Why Rover was driven out of UK Hands' in The Stakeholder Society. Writings in Politics and Economics. Oxford: Polity Press.

Hymer, S. 1975. The Multinational Corporation and the Law of Uneven Development. In Hugo Radice, Ed, International Firms and Modern Imperialism. Handsworth: Penguin.

Jones, G. 1990. The British Government and Foreign Multinationals Before 1970, in M Chick, ed., Governments, Industries and Markets: Aspects of Government-Industry Relations in Great Britain, Japan, West Germany and the United states of America since 1945. Aldershot: Edward Elgar.

Owen, G. 1999. From Empire to Europe. The Decline and Revival of British industry Since the Second World War. London: Harper Collins.

Peoples, J and Sugden, R. 2000. Divide and Rule by Transnationals, in C. Pitelis and R. Sugden, Ed.s, The Nature of the Transnational Firm, Second Edition. London: Routledge.

Ramsay, H. 1992. A Critical Assessment of the 1992 Project Agenda for Industrial Policy, in K Cowling and R Sugden, ed.s, Current Issues in Industrial Strategy. Manchester: Manchester University Press.

Ramsay, H. 1995. Le Défi Européen. Multinational Restructuring, Labour and EU Policy, in A Amin and J Tomaney, ed.s, Behind the Myth of the European Union. Prospects for Cohesion. London: Routledge.

Ravenscraft, D J and F M Scherer. 1989. The Unprofitability of Mergers, International Journal of Industrial Organization, Vol.7

Sally, R. 1996. Public Policy and the Janus Face of the Multinational Enterprise: National Embeddedness and International Production. In P Gummett, ed., Globalization and Public Policy. Cheltenham: Edward Elgar.

Stewart, P, K Murphy, A Danford, T Richardson, M Richardson and V Wass. 2009. We Sell our Time no More: Workers' Struggles against lean Production in the British Car Industry. London: Pluto Press. 
Stopford, J M and L Turner. 1985. Britain and the Multinationals. Chichester: John Wiley.

Williams, K., C. Haslam, S. Johal and J. Williams. 1994a. Cars. Analysis, History, Cases. Providence: Berghahn Books.

Williams, K., C. Haslam and S Johal. 1994b. Who's Responsible? BAe: BMW: Honda: Rover, A Public Interest Report from the Centre for Empirical Research in Accounting and Finance, University of Manchester, and the Business Policy Unit, East London Business School, University of East London. 